\title{
Four new species of fan worms (Polychaeta: Sabellidae) from worldwide localities
}

\author{
MARÍA ANA TOVAR-HERNÁNDEZ ${ }^{1}$ and HARLAN DEAN ${ }^{2}$ \\ ${ }^{1}$ GeoMare A.C., Av. Miguel Alemán 616-4B, Col. Lázaro Cárdenas, 82040, Mazatlán, Sinaloa, México. \\ E-mail: maria_ana_tovar@yahoo.com \\ ${ }^{2}$ Department of Invertebrate Zoology, Museum of Comparative Zoology, Harvard University, 26 Oxford Street, \\ Cambridge, MA 02138, United States. E-mail: harlan.dean@umb.edu
}

\begin{abstract}
SUMMARY: Four new species of soft-bottom sabellid polychaetes are described and illustrated. Branchiomma costaricensis n. sp. is described from $31 \mathrm{~m}$ depth off Isla del Coco, Costa Rica; Dialychone arabica $\mathrm{n}$. sp. from $105 \mathrm{~m}$ depth in the Arabian Sea; Dialychone blakei n. sp. from 487 m depth off Louisiana in the Gulf of México and Paradialychone harrisae n. sp. from $30 \mathrm{~m}$ depth in southern California. Branchiomma costaricensis n. sp. is characterized by having microstylodes with the median pair 1.5 times longer than neighbouring pairs, thoracic uncini with two rows of teeth above the main fang, an unspotted body and large interramal eyespots. Dialychone arabica $\mathrm{n}$. sp. has the anterior peristomial ring lobe exposed beyond the collar and a pre-pygidial depression occupying eight segments. In D. blakei n. sp., the anterior peristomial ring lobe is not exposed beyond the collar, the pre-pygidial depression occupies the last four segments and the posterior segments possess thin elongate, narrowly hooded chaetae. Paradialychone harrisae n. sp. differs from the other species of the genus in having the anterior peristomial ring lobe bilobed and exposed beyond the collar, a rectangular ventral collar shield and paleate chaetae with a long mucro.
\end{abstract}

Keywords: Sabellidae, Branchiomma, Dialychone, Paradialychone.

RESUMEN: Cuatro nuevas especies de gusanos plumero (Polychaeta: Sabellidae) de localidades mundiales. - Se describen e ilustran cuatro nuevas especies de poliquetos sabélidos de fondos blandos. Branchiomma costaricensis $\mathrm{n}$. sp. es descrita para la Isla del Coco, Costa Rica, a $31 \mathrm{~m}$ de profundidad; Dialychone arabica $\mathrm{n}$. sp. para el Mar de Arabia a 105 m; Dialychone blakei n. sp. frente a Louisiana en el Golfo de México a 487 m y Paradialychone harrisae n. sp. para el sur de California a $30 \mathrm{~m}$. Branchiomma costaricensis $\mathrm{n}$. sp. se caracteriza por presentar microstilodos con el par medio 1.5X más largo que los vecinos, uncinos torácicos con dos hileras de dientes sobre el diente principal, cuerpo amaculado y manchas interramales grandes. Dialychone arabica n. sp. tiene el lóbulo del anillo peristomial anterior expuesto sobre el collar y la depresión pre-pigidial ocupa ocho segmentos. En D. blakei n. sp., el lóbulo del anillo peristomial anterior no está expuesto sobre el collar, la depresión pre-pigidial está formada por cuatro segmentos y los segmentos posteriores poseen setas extremadamente largas. Paradialychone harrisae n. sp. difiere de otras especies del género por presentar el lóbulo del anillo peristomial anterior bilobulado y expuesto sobre el collar, un cojinete ventral del collar rectangular y setas paleadas con mucro largo.

Palabras clave: Sabellidae, Branchiomma, Dialychone, Paradialychone.

\section{INTRODUCTION}

Sabellidae Latreille, 1825 is a family of polychaetous annelids commonly known as fan worms, featherduster worms, or sea flowers. Living specimens are easily recognized due to their often colourful crown frequently projecting from the mouth of their tubes. Rioja (1923) divided the sabellids into three subfamilies based primarily on chaetal characters: Sabellinae Latreille, 1825, Myxicolinae Koch in Renier, 1847 and Fabriciinae Rioja, 1923. Fitzhugh's (1989) morphology-based cladistic analysis resulted in significant 
changes to the previous classification of Sabellidae as it demonstrated that only the subfamilies Fabriciinae and Sabellinae could be accepted as monophyletic. The most recent reviews of Fabriciinae bring the number of nominal species to more than 70 (Fitzhugh, 1998, 1999), while the Sabellinae was emended by Fitzhugh (1991) to include more than 400 nominal species.

Recently, Kupriyanova and Rouse (2008) studied the monophyly of the Sabellidae based on molecular data from three nuclear genes of sabellins and fabricins. Their molecular evidence supports the hypothesis that the Sabellidae does not constitute a monophyletic group as currently formulated since it contains the Serpulidae. Additionally, the Fabriciinae were found to be more closely related to the Serpulidae than to Sabellinae. The authors therefore emphasized that the Fabriciinae must be removed from the Sabellidae and be referred to the Fabriciidae, with the revised Sabellidae being equal to the previous subfamily Sabellinae because its represents the simplest solution with the least disruption to current nomenclature.

Worldwide systematic revisions have been done for the sabellid genera Dialychone Claparède, 1870 and Paradialychone Tovar-Hernández, 2008. As a result their taxonomy is better studied and several species have been described within these genera (Tovar-Hernández, 2007; Nishi et al., 2009). The genus Branchiomma Kölliker, 1859 has only partial revisions from the Caribbean Sea (Tovar-Hernández and KnightJones, 2006) and the Mediterranean Sea (Licciano and Giangrande, 2008), and phylogenetic analyses have not been performed.

In this contribution four new species of Branchiomma, Dialychone and Paradialychone are described from isolated localities in Costa Rica, the Arabian Sea, southern California and the northern Gulf of México.

\section{MATERIALS AND METHODS}

The materials examined are deposited in the Los Angeles County Museum of Natural History, Allan Hancock Foundation (LACM-AHF), the Museum of Comparative Zoology, Harvard University (MCZ) and the Museo de Zoología, Universidad Nacional de Costa Rica (MZUCR). Descriptions are based on holotypes with data in parentheses referring to the paratypes. The methyl green staining for Dialychone and Paradialychone species follows Hofsommer (1913). A Leica MZ75 stereomicroscope and Olympus CH30 optical microscope were used for identification, digital photographs were taken with an attached Canon S5 digital camera, and drawings were made using a camera lucida. Materials were processed and examined after final dehydration in two changes of $100 \%$ ethanol at the Laboratorio de Microscopía Electrónica de Barrido (Facultad de Ciencias, Universidad Nacional Autónoma de México). Specimens of Dialychone and Paradialychone were critical-point dried, mounted on stubs and coated with gold ( $200 \AA$ ) before examination with a Cambridge 250 scanning electron microscope (SEM). A specimen of Branchiomma costaricensis n. sp. was critical-point dried and coated with gold (20 A) at the MCZ by one of us (HD) and examined using a Zeiss EVO 50 Scanning Electron Microscope. In descriptions, data in parenthesis refer to paratypes.

\section{RESULTS}

Family SABELLIDAE Latreille, 1825

Genus Branchiomma Kölliker, 1859

Branchiomma costaricensis $\mathrm{n}$. $\mathrm{sp}$. (Figs 1A-H, 2A-I, 7A-E)

Type material: Holotype (MCZ 85000), 10 paratypes (MCZ 87197) and one paratype mounted in gold for SEM (MCZ 87606): Bahía Chatam, Isla del Coco, Costa Rica, sediment/algae, October 12, 2007, bottom trawl, $31.7 \mathrm{~m} ; 2$ paratypes (MZUCR 230-03) Bahía Chatam, Isla del Coco, Costa Rica, April 7, 2008, bottom trawl, $60 \mathrm{~m}$.

Diagnosis. Digitiform microstylodes with the median pair 1.5 times longer than neighbouring pairs; unsegmented radiolar rachis; thoracic uncini with two rows of teeth above the main fang; unspotted body and large interramal eyespots.

Description. Body excluding crown $7 \mathrm{~mm}$ long (1.5-9), $0.5 \mathrm{~mm}$ wide (0.25-0.5). Body pale, lacking pigmentation on the dorsal and ventral surfaces. Large, dark interramal spots along entire body (Figs $1 \mathrm{G}, 7 \mathrm{C})$, slightly smaller in last posterior segments. Radiolar crown $5 \mathrm{~mm}$ long (0.5-6), extending 0.5 to 0.75 times body length, united at base by short web or membrane. Radiolar base with longitudinal bands of diffuse brown spots, below web. Eight pairs of radioles (4-7) with filiform tips (Fig. 1A), with narrow brown bands extending towards pinnular tips, each band occupying the space of three pinnules. Longest pinnules at 0.75 times branchial crown length. Basal stylode unpaired, small, digitiform, 0.25 times rachis width (Figs 1D, 2A); seven to eight pairs of small, digitiform microstylodes (Figs 1A-D, 2A-B); median pair 1.5 times as long as adjacent pairs, flanking median area of radiole (Fig. 1B-C). Unsegmented radiolar rachis. Eight pairs of oval compound eyes (4-10) one each side of rachis, ommatidia sub-conical (Fig. 2A-B); those of median and distal region surrounded by accumulation of pigment cells; eyes lacking between last pair of stylodes (Fig. 1A). Dorsal lips of 0.25 times the length of radioles, triangular with distinct longitudinal ridge (mid-rib); ventral lips rounded, 0.25 times the length of dorsal lips; ventral sacs rounded (Fig. 7B). Midline faecal groove deep on first segment forming mounds on each side; collar well separated dorsally (Figs 1F, 7A), lateral collar margins transverse to body axis covering junction between crown and body; ventral lappets (with brown spots) with rounded apices, overlapping medially (Figs 1E, 7B-C). Thorax with five segments (4-7). Thoracic tori extending to sides of brown, trapezoidal ventral shields, latter two times 

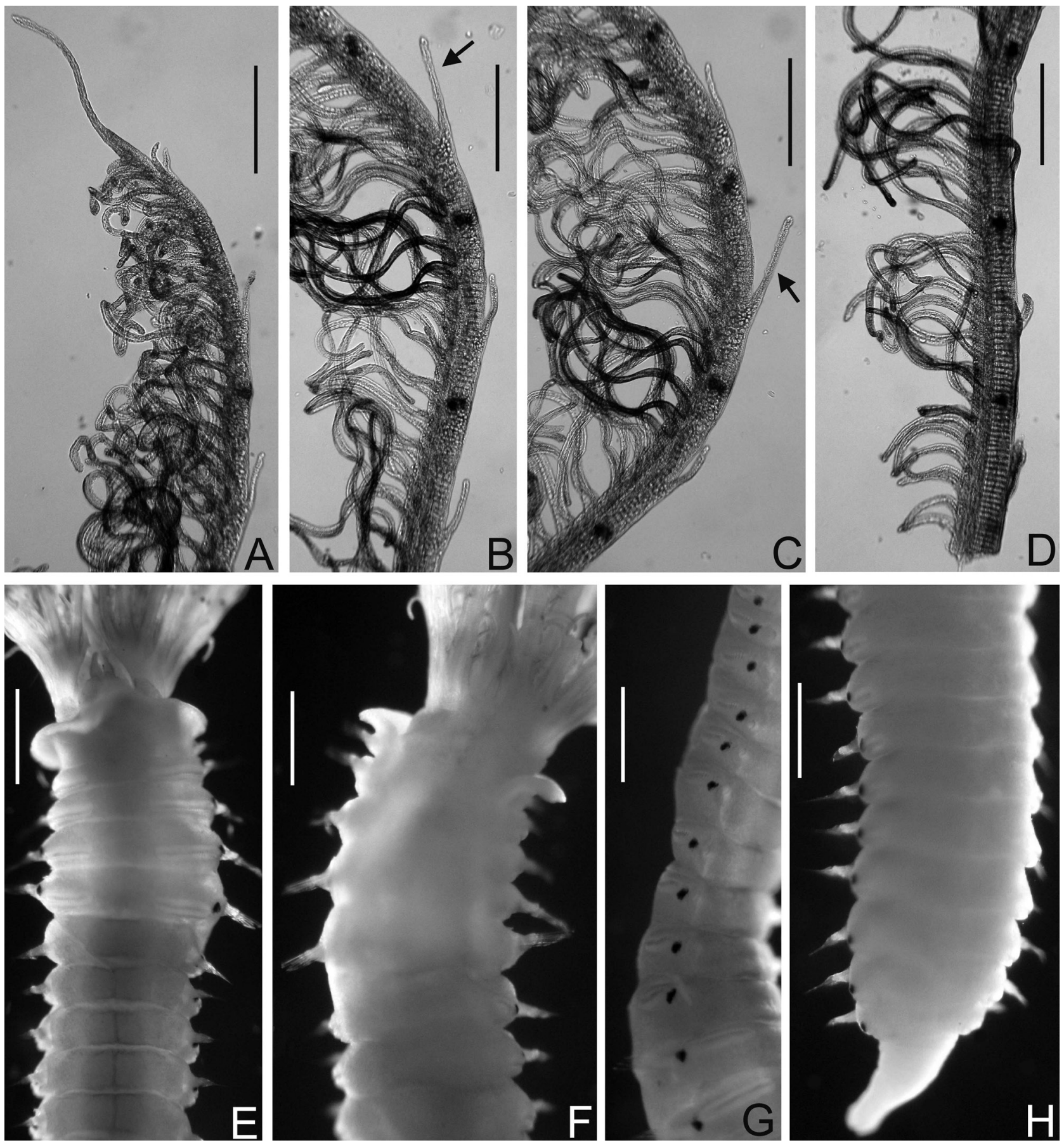

FIG. 1. - Branchiomma costaricensis n. sp. A, radiolar tip; B-C, median stylodes as indicated with arrows; D, base of a lateral radiole; E, thorax, ventral view; F, thorax, dorsal view; G, interramal abdominal spots; H, posterior end. A-D, paratype; E-H, holotype. Scale bars: A-D, $0.25 \mathrm{~mm}$; E-H, $1 \mathrm{~mm}$.

wider than long (Fig. 1E). Collar chaetae slender, narrowly hooded arranged in compact fascicles (Fig. 2G). Thoracic notochaetae arranged within each fascicle in irregular oblique rows of superior and inferior chaetae; superior chaetae slender, hooded, knee region slightly wider than shaft; inferior chaetae with knee up to twice as wide as shaft (Fig. 2C). Avicular uncini with two rows of teeth (seen laterally) occupying 0.5 times main fang length (Fig. 2D-E), with short, curved handle (Fig.
7D). Abdomen with 20 segments (19-44); conical tori smaller than those of thorax. Fascicles of abdominal chaetae forming compact tufts (Fig. 2I), superior chaetae narrowly hooded, arranged in thick C-shaped arc around cluster of capillary chaetae (Fig. 2H-I); number of chaetae per fascicle decreases gradually towards posterior. Abdominal uncini with two rows of teeth and short straight manubrium (Figs 2F, 7E). Bilobed pygidium (Fig. $1 \mathrm{H}$ ). Tubes unknown. 

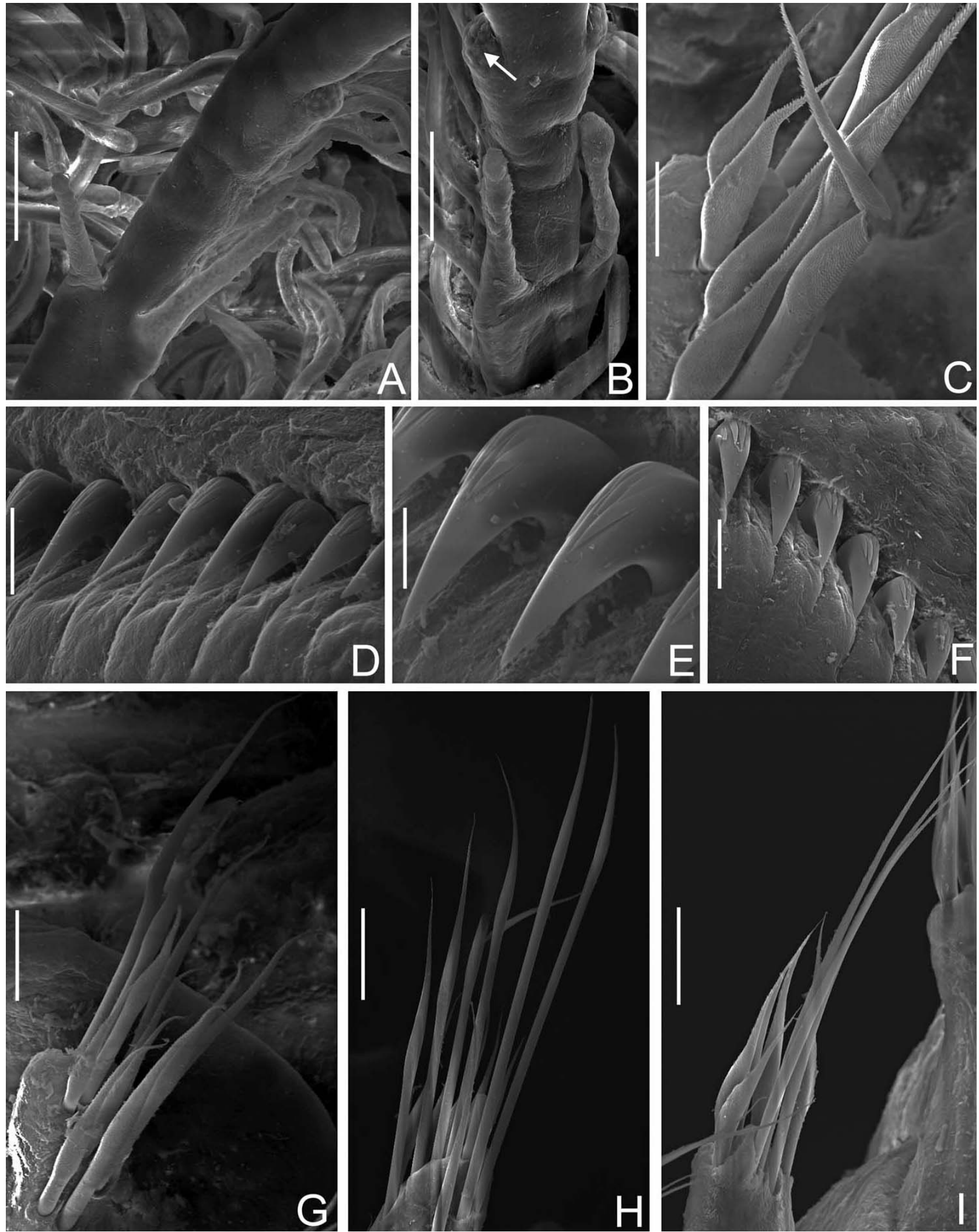

FIG. 2. - Branchiomma costaricensis n. sp. A, basal stylodes; B, median stylodes and radiolar eyes as indicated with arrow; $\mathrm{C}$, thoracic chaetae from chaetiger 2; D-E, thoracic uncini; F, abdominal uncini; G, chaetae from collar segment; H-I, abdominal chaetae. A-I, Gold coated for SEM. Scale bars: A-B, $40 \mu \mathrm{m}$; C-F, $10 \mu \mathrm{m} ; \mathrm{G}-\mathrm{I}, 20 \mu \mathrm{m}$. 
Gametes. One paratype is a simultaneous hermaphrodite, with male and female gametes occurring in the same segments in the anterior abdomen. Sperm with spherical nucleus, rounded cap-like acrosome and a long flagellum.

Etymology. The specific epithet refers to the collecting country, Costa Rica.

Remarks. Branchiomma is a large, widespread, sabellid genus of about 30 species, which are found in sheltered waters such as bays, lagoons and harbours, mainly on floating docks, dock pilings (metal, wood, concrete), floating buoys (metal and PVC) and the hulls of vessels, but also on rocks, coral crevices, sponges and molluscs (Tovar-Hernández and Knight-Jones, 2006). Wide geographical distributions of some sabellid species referred to as cosmopolitan are suspect and detailed study usually finds that more than one species with narrower distributions is involved (Tovar-Hernández and Knight-Jones, 2006; Licciano and Giangrande, 2008). However, at least four species of Branchiomma have been considered as alien (Tovar-Hernández et al., 2009); these include B. luctuosum (Grube, 1870), B. boholense (Grube, 1878), B. curtum (Ehlers, 1901) and B. bairdi (McIntosh, 1885). In order to recognize possible new introductions of alien Branchiomma species in Costa Rica, a comparison of these species and $B$. costaricensis n. sp. is provided: Branchiomma luctuosum, B. curtum and B. costaricensis n. sp. share the presence of microstylodes but $B$. luctuosum differ from the other two species in having the radiolar rachis segmented (not segmented in B. curtum and B. costaricensis $\mathrm{n}$. sp.). Branchiomma costaricensis n. sp. resembles $B$. curtum, in that both species are small; however, B. costaricensis $\mathrm{n}$. $\mathrm{sp}$. has thoracic uncini with main fang surmounted by two rows of teeth (three in $B$. curtum), large interramal spots (small in B. curtum) and short and medium sized stylods (only short in $B$. curtum). Branchiomma boholense and B. bairdi have macrostylodes, while in $B$. costaricensis $\mathrm{n}$. $\mathrm{sp}$. there are only microstylodes. Branchiomma costaricensis n. sp., and $B$. boholense have thoracic uncini with two rows of teeth above the main fang, but B. costaricensis n. sp. has digitiform stylodes (digitiform and flattened, tongue-shaped in B. boholense).

Other species with thoracic uncini with two rows of teeth above the main fang correspond to Branchiomma cingulatum (Grube, 1870) and Branchiomma sp. (Licciano and Giangrande, 2008). Branchiomma costaricensis n. sp. differ from these in having an unsegmented rachis and short, digitiform stylodes $(B$. cingulatum has a segmented rachis with filiform stylods and in $B$. sp. the rachis is unsegmented with long tongue-shaped stylodes).

Six species of Branchiomma are distributed in the tropical American coasts. Among these, B. bairdi and $B$. conspersum (Ehlers, 1887) have short, medium, long and extra-long stylodes in the same radiole; $B$. coheni Tovar-Hernández and Knight-Jones, 2006 has short, medium and long stylodes; $B$. illifei TovarHernández and Knight-Jones, 2006 has medium and long stylodes; $B$. curtum has only short stylodes and B. nigromaculatum (Baird, 1865) and B. costaricensis n. sp. have short and medium stylodes. Branchiomma costaricensis $\mathrm{n}$. sp. differ from B. nigromaculatum in possessing thoracic uncini with the main fang surmounted by two rows of teeth (one in B. nigromaculatum) and an unsegmented radiolar rachis (segmented in B. nigromaculatum).

Species of Branchiomma can lose body spot patterns due to sloughing after imperfect fixation and preservation. Holotype and paratypes examined here have unspotted bodies although further collections are needed to document live coloration.

\section{Genus Dialychone Claparède, 1870 Dialychone arabica $\mathrm{n}$. $\mathrm{sp}$. (Figs 3A-I, 6A-C, 7F-K)}

Type material: Holotype and six paratypes (LACM-AHF 25042505): Oman Margin, northwest Arabian Sea, RRS Discovery Cruise 211, October 27, 1994, $105 \mathrm{~m}, 0-1 \mathrm{~cm}, 12710,1$, Box C, Veg B.

Diagnosis. Anterior peristomial ring lobe entire, exposed beyond the collar; ventral margin of the collar notched; vascular peristomial loops present; short, digitiform radiolar tips; pre-pygidial depression occupying eight segments.

Description. Body excluding crown $2.25 \mathrm{~mm}$ long (2-3), $0.25 \mathrm{~mm}$ wide (0.25); trunk cylindrical with pre-pygidial depression (Fig. 3A). Branchial crown length: $1.75 \mathrm{~mm}$ (1.5-1.75). Four pairs (5) of radioles. Distal pinnules longer than proximal, 0.5 times branchial crown length (Figs 3A-B, 7I); radiolar tips short, digitiform (Fig. 7I). Palmate membrane extends about 0.5 times branchial crown length; insertion of branchial crown not exposed beyond collar (Fig. 3A). Lateral flanges narrow. Single pair of long ventral radiolar appendages: about 0.5 times branchial crown length. Anterior peristomial ring lobe exposed beyond collar (Fig. 3B), distally entire, triangular. Posterior peristomial ring collar with dorsal and lateral margins entire, ventral margin notched (Figs 3B, 7F); lateral margins level (Figs 3A, 7G); narrow gap along entire length of mid-dorsal collar margins. Dorsal pockets well developed with vascular loops (Fig. 7H). Ventral collar shield horseshoe shaped (Fig. 7F). Posterior peristomial ring collar length 1.5 times chaetiger 2 length in lateral view. Thoracic notopodia with elongate, narrowly hooded chaetae (Fig. 3D) and short bayonet chaetae (Fig. 3D). Thoracic neuropodia bearing acicular uncini with long handles (Fig. 7J), teeth decreasing gradually in size away from the main fang; dentition covering 0.75 times main fang length; hood present (Fig. 3E). Thoracic segments biannulate with narrow glandular ridge on chaetiger 2. Abdominal segments 

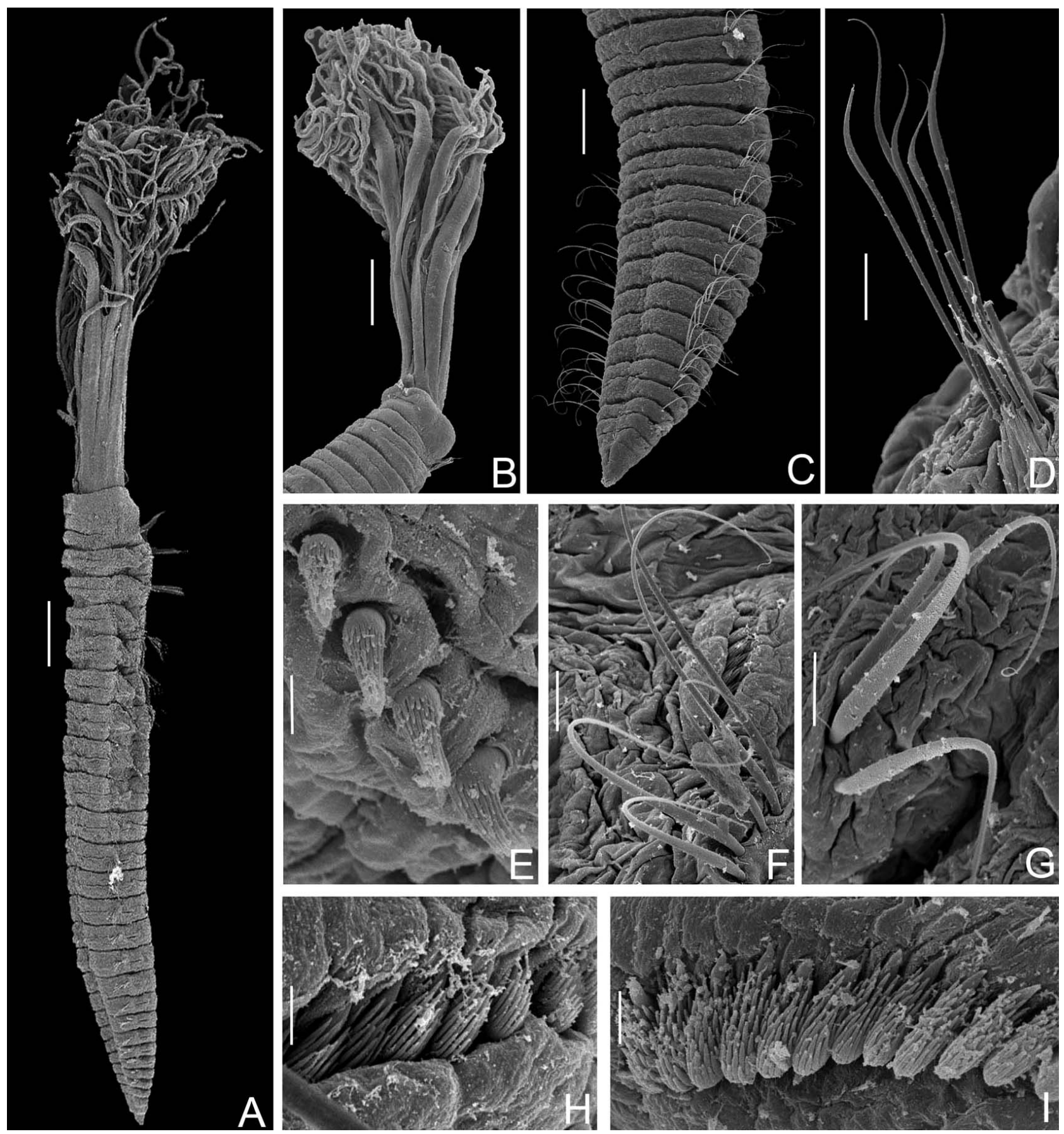

FIG. 3. - Dialychone arabica n. sp. A, body, ventro-lateral view; B, collar and branchial crown, ventral view; C, posterior abdomen; D, thoracic chaetae; E, thoracic uncini; F-G, abdominal chaetae; H, anterior abdominal uncini; I, posterior abdominal uncini. A-I, paratype coated in gold for SEM. Scale bars: A-B, $0.2 \mathrm{~mm}$; C, $0.1 \mathrm{~mm}$; D, $20 \mu \mathrm{m}$; E, H-I, $2 \mu \mathrm{m}$; F-G, $10 \mu \mathrm{m}$.

17 (17-22); anterior segments with two transverse rows of elongate, narrowly hooded chaetae, those of upper row 0.5 times as long as those of lower row (Fig. 3F). Uncini with well-developed rectangular breast, handles absent, main fang well developed with series of nearly uniformly sized teeth covering 0.5 times main fang length. Pre-pygidial depression simple, occupying eight segments (Figs 3A, C, 6C). Posterior segments with elongate, narrowly hooded chaetae, $25 \%$ longer than those of anterior abdominal segments (Fig. 3G); modified uncini with hooked breast, handles absent, main fang surmounted by 6-7 regular vertical rows of equal sized teeth, dentition covering 0.75 times main fang length (Fig. 3H-I). Pygidium with triangular posterior margin, some paratypes with pygidial cirrus (Figs 6A-C, 7F). Tubes unknown.

Gametes. Paratype male containing spermatozoa 

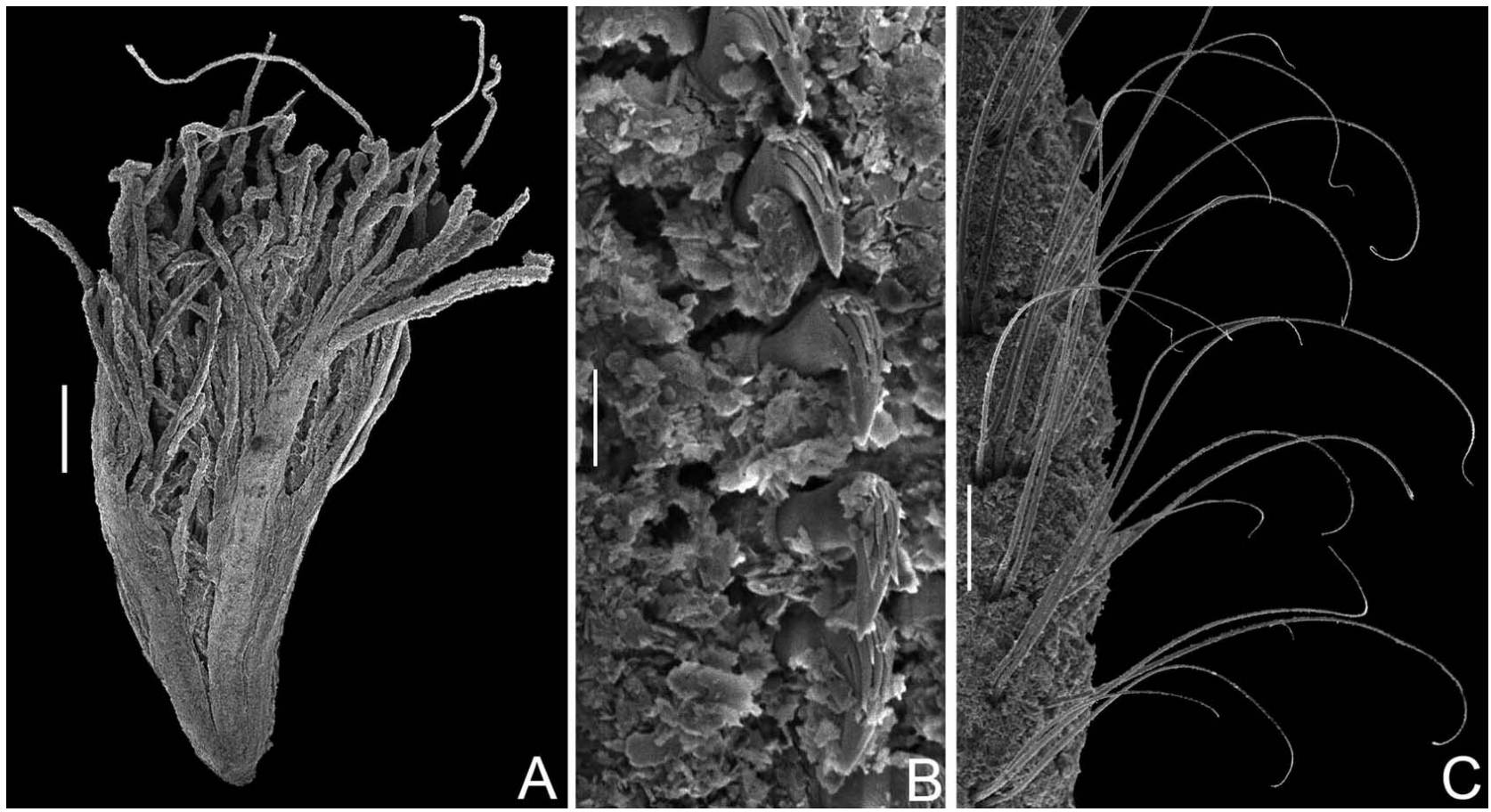

FIG. 4. - Dialychone blakei n. sp. A, branchial crown; B, thoracic uncini; C, abdominal chaetae. A-C, paratype coated in gold for SEM. Scale bars: A, $0.1 \mathrm{~mm} ; \mathrm{B}, 4 \mu \mathrm{m} ; \mathrm{C}, 40 \mu \mathrm{m}$.

with barrel-shaped nucleus, conical acrosome and two rounded mitochondria in anterior abdomen.

Methyl green staining. Ventral shield of collar stained uniformly, except for the anterior end (Figs 6A, $7 \mathrm{~F})$. Lateral margins of ventral shield with scattered glands (Fig. 7F-G). Thorax with highly glandular epidermis, ventral surface staining uniformly except for distinct inter-segmental grooves (Figs 6A, 7F). Scattered glands stained in lateral (Figs 6B, 7G) and dorsal thorax (Fig. 7H). Pigmentation at the posterior end of the body is lost quickly (Fig. 6A-C).

Etymology. The specific name refers to the collecting zone, the Arabian Sea.

Remarks. The genus Dialychone Claparède, 1870 was re-established by Tovar-Hernández (2008) based on the absence of pinnular appendages and the presence of teeth decreasing in size from the main fang in thoracic uncini, and is composed of 14 known species. Among these, Dialychone acustica (Claparède, 1870), D. albocincta (Banse, 1972), D. arenicola (Langerhans, 1880), D. australiensis (Hartman-Schröder, 1979), D. perkinsi (Tovar-Hernández, 2005), D. trilobata (Gallardo, 1968), D. usticensis (Giangrande et al., 2006) and $D$. arabica $\mathrm{n}$. sp. have a distally entire, triangular, anterior peristomial ring lobe, which in the latter two species is exposed beyond the ventral collar margin (not exposed in all other species). Dialychone arabica n. sp. differs from $D$. usticensis in having the ventral margin of the collar notched (unnotched in D. usticensis); vascular peristomial loops (absent in D. usticen- sis); short, digitiform radiolar tips (long and filiform in D. usticensis); and with the longest pinnules 0.75 times the branchial crown length (equal in size along the entire radiole in D. usticencis). Dialychone arabica $\mathrm{n}$. sp. differ from $D$. blakei $\mathrm{n}$. sp. in having a pygidium with a triangular posterior margin (rounded in D. blakei $\mathrm{n}$. $\mathrm{sp}$.); a triangular anterior peristomial ring lobe (bilobed in D. blakei n. sp.), short radiolar tips (very long in $D$. blakei $\mathrm{n}$. sp.) and a posterior pre-pygidial depression occupying eight segments (four segments in D. blakei n. sp.).

The vascular loops of D. arabica n. sp., are circular cavities situated dorsollaterally on the peristomium; inside each cavity there is an S-shaped vessel. These structures have also been recorded by Tovar-Hernández, (2008) in Euchone analis Krøyer, 1856, Jasmineira Langerhans, 1880, and Fabrisabella Hartman, 1969.

\section{Dialychone blakei n. sp. (Figs 4A-C, 6D-E, 7L-O)}

Type material: Holotype (MCZ 86000), 6 paratypes (MCZ 87196) and one paratype mounted in gold for SEM: Gulf of México, off Louisiana, $28^{\circ} 48.3506^{\prime} \mathrm{N}, 88^{\circ} 55.9618^{\prime} \mathrm{W}, 487 \mathrm{~m}, 0.25 \mathrm{~m}^{2}$ box core, July 10, 2008, R/V Brooks McCall, Donor J.A. Blake.

Diagnosis. Anterior peristomial ring lobe bilobed, not exposed beyond the collar; filiform radiolar tips extra long, up to 0.5 times branchial crown length; prepygidial depression occupying four segments; posterior abdominal segments with very elongate, narrowly hooded chaetae $(50 \%$ longer than those of anterior abdominal segments). 

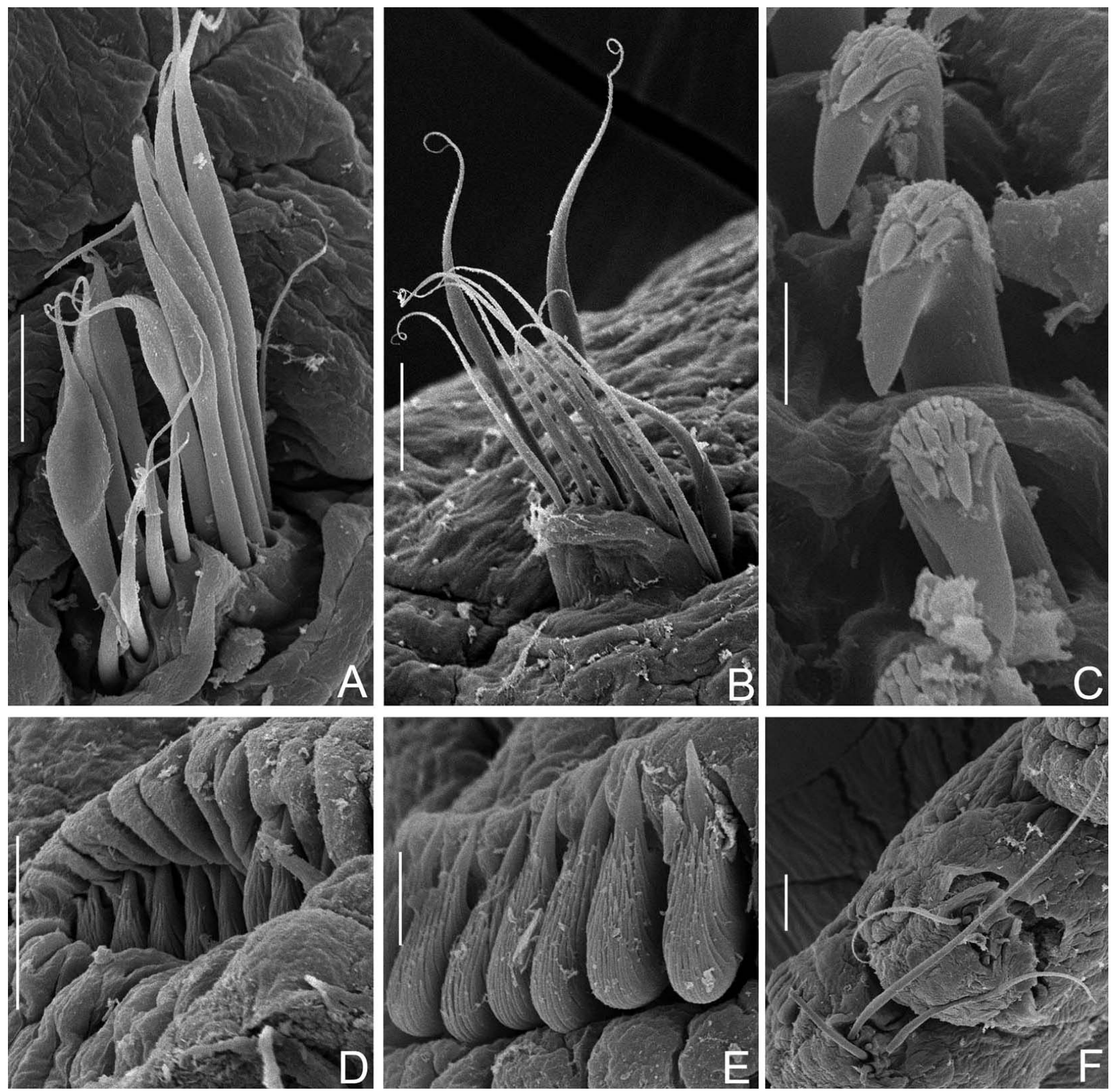

FIG. 5. - Paradialychone harrisae n. sp. A, thoracic chaetae; B, bayonet chaetae; $\mathrm{C}$, thoracic uncini; $\mathrm{D}$, anterior abdominal uncini; E, posterior abdominal uncini; F, abdominal chaetae. A-F, Paratype coated in gold for SEM. Scale bars: A-B, D, F, $10 \mu \mathrm{m} ; \mathrm{C}, 2 \mu \mathrm{m}$; E, $4 \mu \mathrm{m}$.

Description. Body excluding crown $0.75 \mathrm{~mm}$ long $(0.75-2), 0.2 \mathrm{~mm}$ wide $(0.20-0.25)$; trunk cylindrical, posterior abdomen depressed dorso-ventrally. Branchial crown length $0.5 \mathrm{~mm}(0.5)$, three pairs (3) of radioles; distal pinnules longer than more proximal pinnules, 0.5 times branchial crown length (Fig. 4A); filiform radiolar tips extra long, up to 0.5 times branchial crown length (Fig. 4A). Palmate membrane about 0.5 times branchial crown length. Lateral flanges narrow. Bilobed anterior peristomial ring lobe not exposed beyond collar, posterior peristomial ring collar margins entire decreasing in length dorsally with narrow gap along entire length of mid-dorsal collar margins (Fig. 6D); dorsal pockets well developed. Ventral collar shield horseshoe shaped, almost indiscernible. Posterior peristomial ring collar 1.5 times length of chaetiger 2 in lateral view, covering junction of body and crown. Thoracic notopodia with elongate, narrowly hooded chaetae and short bayonet; thoracic neuropodia bearing acicular uncini with long handles (Fig. 7M), teeth decreasing gradually in size away from the main fang, dentition cover 0.5 to 0.75 times main fang length; hood present (Figs 4B, 7M). Thoracic segments biannulate with narrow glandular ridge on chaetiger 2. Eleven abdominal segments (10-14) with two transverse rows of elongate, narrowly hooded 
chaetae in anterior segments; superior row chaetae 0.5 times length of those of inferior row; uncini with well-developed rectangular breast, handles absent, main fang well developed with a series of nearly uniformly sized teeth covering 0.5 times main fang length (Fig. 7N). Pre-pygidial depression simple, occupying four segments. Posterior segments with very elongate, narrowly hooded chaetae, $50 \%$ longer than those of anterior abdominal segments (Figs 4C, 6E); modified uncini with hooked breast, handles absent, main fang surmounted by 6-7 regular vertical rows of equal sized teeth covering 0.75 times main fang length (Fig. 7O). Pygidium with rounded posterior margin (Figs 6D-E, 7L). Tubes unknown.

Gametes. Paratype female with oocytes in anterior abdomen.

\section{Methyl green staining. Undetermined.}

Etymology. This species is named in honour of Dr. James A. Blake (ENSR Marine and Coastal Center), who collected the materials and kindly sent them to us for their study.

Remarks. Dialychone veleronis (Banse, 1972), D. collaris (Langerhans, 1880), D. normani (McIntosh, 1916), D. dunerificta (Tovar-Hernández et al., 2007), D. longiseta (Giangrande, 1992), D. quebecensis (Tovar-Hernández, 2007), D. trilineata (TovarHernández, 2007) and D. blakei n. sp. have a bilobed anterior peristomial ring lobe. Among these, D. blakei n. sp. is unique in that the anterior peristomial ring lobe is not exposed beyond the collar, the filiform radiolar tips are extra long (up to 0.5 times branchial crown length), the posterior pre-pygidial depression occupies the last four segments, and the posterior abdominal segments possess very elongate, narrowly hooded chaetae $50 \%$ longer than those of anterior abdominal segments).

\section{Genus Paradialychone Tovar-Hernández, 2008 Paradialychone harrisae n. sp. (Figs 5A-F, 6F-I, 7P-R)}

Type material: Holotype (LACM-AHF 2243): southern California, off Lunada Bay, 3346.02'N, $118^{\circ} 26.03^{\prime}$ 'W, July 13, 2005, $30 \mathrm{~m}$ (0705-1D). Eight paratypes (LACM-AHF 2244-2250): $33^{\circ} 42.83^{\prime} \mathrm{N}$, $118^{\circ} 20.55^{\prime} \mathrm{W}$, July 12 , 2006, $30 \mathrm{~m}(0706-7 \mathrm{D}) ; 33^{\circ} 38^{\prime} 41^{\prime}, \mathrm{N}$, $118^{\circ} 8^{\prime} 40^{\prime}$ 'W, July $15,1994,30 \mathrm{~m}$ (PLABE 13320$)$; $33^{\circ} 48.14^{\prime} \mathrm{N}$,

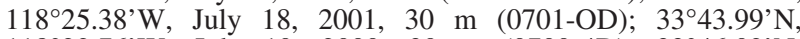
$118^{\circ} 22.76^{\prime} \mathrm{W}$, July $10,2000,30 \mathrm{~m}$ (0700-4D); $33^{\circ} 46.02^{\prime} \mathrm{N}$, $118^{\circ} 26.03^{\prime} \mathrm{W}$, January $12,1994,30 \mathrm{~m}(0194-1 \mathrm{D}) ; 33^{\circ} 44.57^{\prime} \mathrm{N}$ $118^{\circ} 25.21^{\prime} \mathrm{W}$, January 16, 1996, $30 \mathrm{~m}(0197-2 \mathrm{D}) ; 33^{\circ} 43.03^{\prime} \mathrm{N}$, $118^{\circ} 20.82^{\prime} \mathrm{W}$, January $12,1994,30 \mathrm{~m}$ (0194-6D); $33^{\circ} 46.02^{\prime} \mathrm{N}$, $118^{\circ} 26.03^{\prime} \mathrm{W}$, January $14,1993,30 \mathrm{~m}$, mounted in gold for SEM (0193-1D).

Diagnosis. Anterior peristomial ring lobe bilobed, exposed beyond collar; rectangular ventral collar shield; paleate chaetae with long mucro; pre-pygidial depression composed of six segments.
Description. Body excluding crown $6 \mathrm{~mm}$ long (3-12), $0.25 \mathrm{~mm}$ wide $(0.25)$; trunk cylindrical, posterior abdomen dorso-ventrally depressed (Fig. 6G). Branchial crown length $1.5 \mathrm{~mm}$ (1-1.75); six pairs of radioles (3-4); longest pinnules very long, 0.75 times branchial crown, length radiolar tips long, filiform. Palmate membrane extends to 0.5 times branchial crown length. Lateral flanges broad (Fig. 6H); dorsal lips triangular, 2 times longer than wide, without midrib (Fig. 6I). Single pair of short, dorsal pinnular appendages; ventral lips rounded, about 0.25 times dorsal lip length (Fig. 6I); three short pairs of ventral radiolar appendages. Anterior peristomial ring lobe exposed beyond collar, distally bilobed; antero-dorsal margin of posterior peristomial ring collar forming two well developed dorsal pockets, entire length of mid-dorsal collar margin forms narrow gap; lateral, dorsal and ventral margins entire (Figs 6F, 7P-Q), ventral margin slightly higher than dorsal (Fig. 6F); insertion of the branchial lobes exposed dorsally beyond collar. Ventral shield of collar rectangular. Posterior peristomial ring collar 1.5 times chaetiger 2 length in lateral view. Thoracic notopodia with elongate, narrowly hooded chaetae; short bayonet chaetae (Fig. 5A-B) and paleate chaetae with very long mucro (Fig. 5A). Thoracic neuropodia bearing acicular uncini with large tooth offset from midline accompanied by series of smaller teeth; dentition covering 0.5 times main fang length (Fig. 5C); hood present, handles long. Thoracic segments biannulate with narrow glandular ridge on chaetiger 2. Abdominal segments 22 (21-26); anterior segments with two transverse rows of elongate, narrowly hooded chaetae, chaetae from the anterior row shorter than chaetae in posterior row; uncini with well developed rectangular breast, main fang well developed with large tooth above main fang in midline, followed by a series of smaller teeth covering 0.5 times main fang length. Simple pre-pygidial depression composed of six segments. Posterior segments: 1-2 very elongate, upwardly directed chaetae with narrow hoods (Fig. $5 \mathrm{~F})$; modified uncini with hooked breast lacking handles, dentition covering 0.75 times main fang length (Figs 5D-E). Pygidium with triangular posterior margin (Figs 6G, 7R). Tubes unknown.

\section{Gametes. Unknown.}

Methyl green staining. Collar with two triangular glandular areas dorsally (Fig. 7Q), these extend laterally towards the ventral side (Fig. 7P), where only the ventral shield of the collar is stained (Fig. 6A). Sparse glands are distributed along the entire body. Pygidium deeply coloured (Fig. 7A).

Etymology. This species is named in honour of Leslie Harris (Los Angeles County Museum of Natural History) in recognition of her important contributions to the knowledge of polychaetes from California, as well as her continuous support to the Mexican col- 

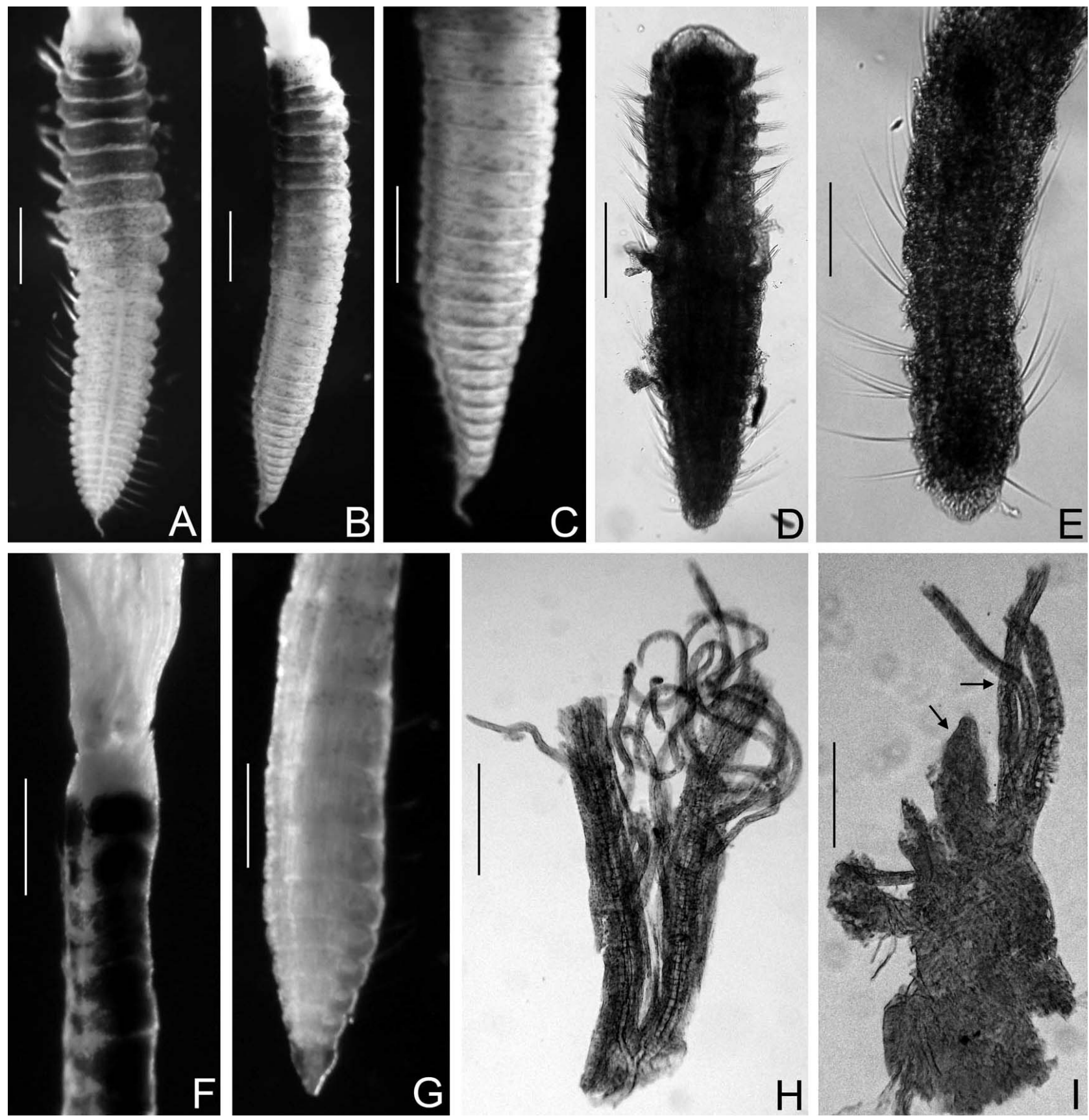

FIG. 6. - Body and branchial crown structures. Dialychone arabica n. sp., holotype: A, body, ventral view; B, body, lateral view; C, body, posterior abdomen, lateral view. Dialychone blakei $\mathrm{n}$. sp., holotype: $\mathrm{D}$, body, dorsal view; E, posterior abdomen, ventral view. Paradialychone harrisae n. sp., holotype and paratype: F, thorax, ventro-lateral view; G, posterior abdomen, lateral view; H, radioles; I, dorsal lip and dorsal pinnular appendages. Scale bars: A-B, D, $0.2 \mathrm{~mm}$; C, E, $0.1 \mathrm{~mm}$; F-G, $0.5 \mathrm{~mm} ; \mathrm{H}, 0.35 \mathrm{~mm}$; I, $0.15 \mathrm{~mm}$.

leagues to facilitate the research in the country for this group of invertebrates.

Remarks. Paradialychone is composed of 12 species. Among these, P. filicaudata (Southern, 1914), $P$. gambiae (Tovar-Hernández et al., 2007), P. bimaculata (Banse and Nichols, 1968) and P. harrisae n. sp. have the anterior peristomial ring lobe bilobed and exposed beyond the collar (triangular or digitiform in other species). Paradialychone gambiae is distinguished by a glandular ridge in the first abdominal segment (absent in P. filicaudata, P. bimaculata and P. harrisae $\mathrm{n}$. sp.). Paradialychone bimaculata has a broad glandular ridge in chaetiger 2 (narrow in $P$. filicaudata and $P$. harrisae n. sp.). Paradialychone harrisae n. sp. differs from $P$. filicaudata in having the longest pinnules at 0.75 times the radiolar length (all pinules are long in $P$. filicaudata), a rectangular ventral collar shield (trapezoidal in P. filicaudata), and paleate chaetae with a long mucro (short in P. filicaudata). Before being 

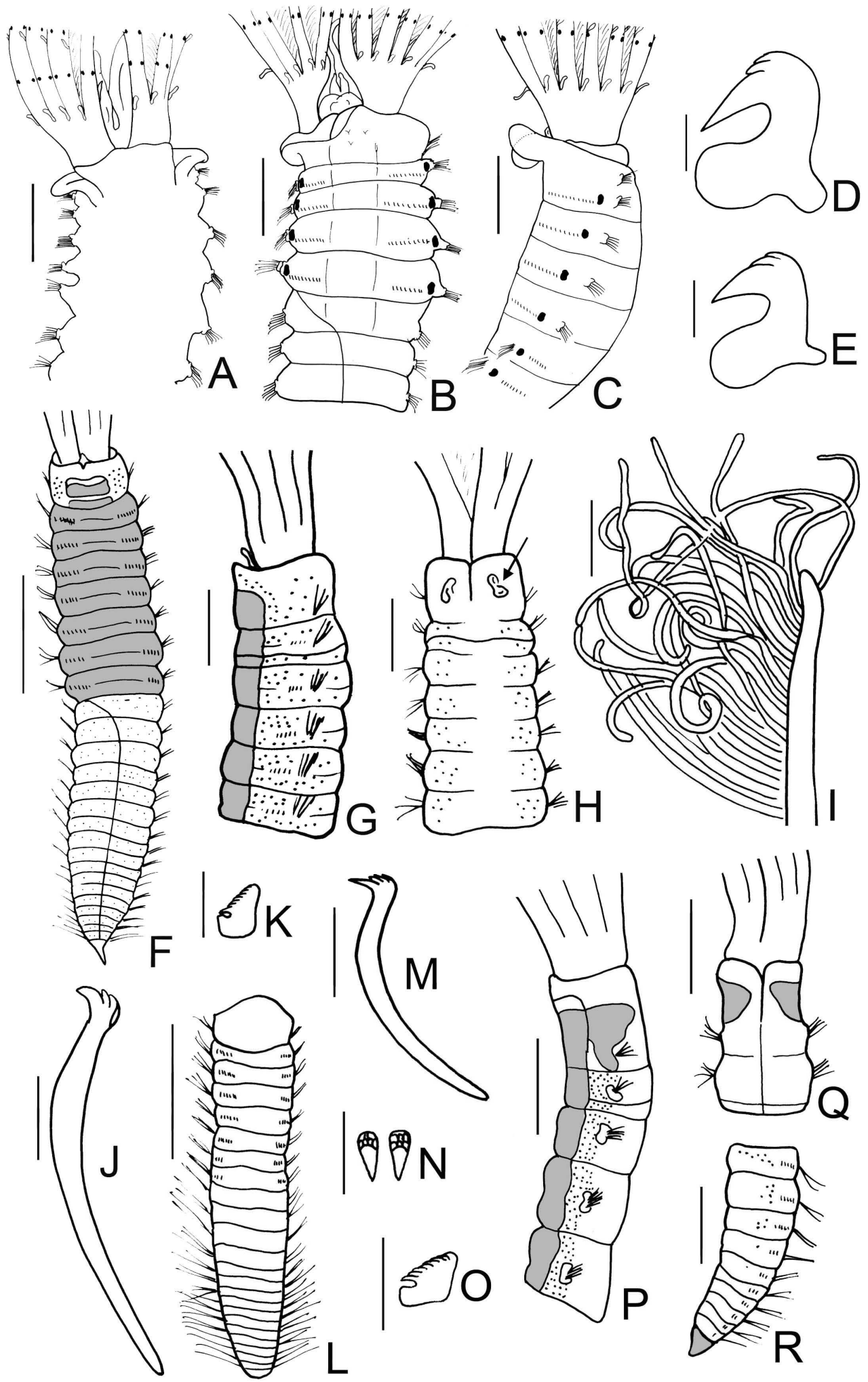

Fig. 7. - Body structures and uncini. Branchiomma costaricensis n. sp., holotype: A, thorax, dorsal view, B, thorax, ventral view, C, thorax, lateral view, D, thoracic uncinus, E, abdominal uncinus. Dialychone arabica n. sp., holotype: F, body, ventral view; G, thorax, lateral view; H, thorax, dorsal view, arrow indicated the peristomial vascular coils; I, radiole; J, thoracic uncinus; K, posterior abdominal uncinus. Dialychone blakei $\mathrm{n}$. sp., paratype, L, body; ventral view; M, thoracic uncinus; N, anterior abdominal uncini; O, posterior abdominal uncinus. Paradialychone harrisae n. sp., paratype: P, thorax, lateral view; Q, collar, dorsal view; R, posterior abdomen, lateral view. R-T, methyl green staining pattern shading in grey. Scale bars: A-C, F, P-R, $0.5 \mathrm{~mm}$; D-E, J-K, M-O, $12.5 \mu \mathrm{m}$; G-H, $0.3 \mathrm{~mm}$; I, $0.25 \mathrm{~mm}$. 
named properly, Paradialychone harrisae n. sp., was referred to as Chone sp. B Harris by the members of the Southern California Association Marine Invertebrate Taxonomist (SCAMIT).

\section{ACKNOWLEDGEMENTS}

Leslie Harris (Los Angeles County Museum of Natural History), James Blake (ENSR Marine and Coastal Center) and Larry Lovell (Marine Biology Laboratory, Los Angeles County Sanitation Districts) provided specimens for study. Special thanks are also given to Silvia Espinosa Matías (Laboratorio de Microscopía Electrónica de Barrido, Facultad de Ciencias, UNAM) for her help in processing SEM photographs. Scanning Electron Microscope help was also provided by Ellen Hodges, Harvard Center for Nanoscale Sciences, Faculty of Arts of Sciences, Harvard University.

\section{REFERENCES}

Baird, W. - 1865. On new tubiculous annelids, in the collection of the British Museum. J. Linnean Soc., 8: 157-160.

Banse, K. - 1972. Redescription of some species of Chone Kröyer and Euchone Malmgren, and three new species (Sabellidae, Polychaeta). Fish. Bull. Wildlife Serv. US Dep. Int., 70: 459-495.

Banse, K. and F.H. Nichols. - 1968. Two new species and three new records of benthic polychaetes from Puget Sound (Washington). Proc. Biol. Soc. Wash., 81: 223-230.

Claparède, E. - 1870. Les annélides chétopodes du Golfe de Naples, Supplément. Mém. Soc. Phys. Hist. Nat. Genève, 20: 137-154.

Ehlers, E. - 1887. Report on the Annelids. Florida-Anneliden. Reports on the Result of Dredging, under the direction of Pourtalès, during the years 1868-1870, and of Alexander Agassiz, in the Gulf of Mexico (1877-78), and in the Caribbean Sea (1878$79)$, in the U.S. Coast Survey steamer "Blake", Lieut. Com. C.D. Sigsbee, U.S.N., and Commander J.R. Bartlett, U.S.N., Commanding. Mem. Comp. Zool. Harv., 15: 1-335.

Ehlers, E. - 1901. Die Polychaeten des magellanischen und chilenischen Strandes: Ein faunisticher Versuch. Fetschrift zur Feier des 150 jährigen Bestehens der Königlichen Gesellschaft der Wissenschaften zu Göttingen. Weidmannsche Buchhandlung, Berlin.

Fitzhugh, K. - 1989. A systematic revision of the SabellidaeCaobangiidae-Sabellongidae complex (Annelida: Polychaeta). Bull. Am. Mus. Nat. Hist., 192: 1-104.

Fitzhugh, K. - 1991. Further revisions of the Sabellidae subfamilies and cladistic relationships among the Fabriciinae (Annelida: Polychaeta). Zool. J. Linn. Soc., 102: 305-322.

Fitzhugh, K. - 1998. New fan worm genera and species (Polychaeta, Sabellidae, Fabriciinae) from the Western Pacific, and cladistic relationships among genera. Zool. Scr., 27: 209-245.

Fitzhugh, K. - 1999. New fanworm species (Polychaeta: Sabellidae: Fabriciinae) from Phuket, Thailand, with comments on Fabriciola flammula Rouse and Fabricola cri Rouse. Contr. Sci., 477: 1-17.

Gallardo, V.A. - 1968. Polychaeta from the Bay of Nha Trang, South Vietnam. Naga Rep., 4: 35-279.

Giangrande, A. - 1992. The genus Chone (Polychaeta, Sabellidae) in the Mediterranean Sea with description of $C$. longiseta n. sp. Boll. Zool., 59: 517-529.

Giangrande, A., M. Licciano and L. Castriota. - 2006. Description of Chone usticensis n. sp. (Polychaeta, Sabellidae) from the Mediterranean Sea. Zootaxa, 1168: 51-58.

Grube, A.E. - 1870. Über die Goldkronchen (Sabellarien oder Hermellen). Schles. Gesells. Vaterl. Kultur, Breslau, Jahresber, 47: 69-70.

Grube, A.E. - 1878. Annulata Semperiana. Beiträge zur Kenntniss des Anneliden fauna der Philippen nach den von Herrn Prof.
Semper mitgebrachten Sammlungen. Mém. Acad. Imp. Sci. St. Petersburg, 25: 1-300.

Hartman, O. - 1969. Atlas of the Sedentariate Polychaetous Annelids from California. University of the Southern California, Allan Hancock Foundation, Los Angeles.

Hartmann-Schröder, G. - 1979. Die Polychaeten der tropischen Nordwestküste Australiens (zwischen Derby im Norden und Port Hedland im Süden). Teil 2. In: G. Hartmann-Schröder and G. Hartmann (eds.), Zur Kenntnis des Eulitorals der australischen Küsten unter besonder Berücksichtigung der Polychaeten und Ostracoden. Mitt. Hamb. Zool. Mus. Inst., 76: 77-218.

Hofsommer, A. - 1913. Die Sabelliden-Ausbeute der 'Poseidon'Fahrten und die Sabelliden der Kieler Bucht. Wiss. Meeresunters, Kiel, 15: 305-364.

Kölliker, H. - 1859. Über Kopfkiemer mit Augen an den Kiemen (Branchiomma dalyelli). Z. Wiss. Zool, Leipzig, 9: 356-541.

Krøyer, H. - 1856. Bidrag til Kundskab af Sabellerne. Kongelige Danske Videnskabernes Selskabs Forhandlinger, 1856: 1-36.

Kupriyanova, E.K. and G.W. Rouse. - 2008. Yet another example of paraphyly in Annelida: Molecular evidence that Sabellidae contains Serpulidae. Mol. Phyl. Evol., 46: 1174-1181.

Langerhans, P. - 1880. Die Wurmfauna von Madeira, 2. Z. W. Zool., 33: 271-316.

Latreille, P.A. - 1825. Familles Naturelles du Règne Animal exposées succinctement et dans un ordre analytique avec l'indication de leurs genres etc. Baillière JB, Paris.

Licciano, M. and A. Giangrande. - 2008. The genus Branchiomma (Polychaeta: Sabellidae) in the Mediterranean Sea, with the description of B. maerli n. sp. Sci. Mar., 72(2): 383-391.

McIntosh, W.C. - 1885. Report on the Annelida Polychaeta collected by H.M.S. Challenger during the years 1873-76, Part 34. Report of the scientific results of the voyage of H.M.S. Challenger London, Zool, 12: 1-554.

McIntosh, W.C. - 1916. Notes from the Gatty Marine Laboratory, St. Andrews, 38. 1. On the British Sabellidae. 2. On the Sabellidae dredged by H.M.S. 'Porcupine' in 1869 and 1870 , and by H.M.S. 'Knight Errant' in 1882. 3. On the Terebellidae and Sabellidae dredged in the Gulf of St. Lawrence, Canada by Dr. Whiteaves in 1871-73. 4. On the Sabellidae dredged by Canon A.M. Norman in Norway and Finmark. Ann. Mag. Nat. Hist., 17: 1-66.

Nishi, E., T. Tanaka, M.A. Tovar-Hernández and A. Giangrande. - 2009. Chone, Dialychone and Jasmineira (Annelida: Polychaeta: Sabellidae) from Japan and adjacent waters, including four new species descriptions. Zootaxa, 2167: 1-24.

Renier, S.A. - 1847. Osservazioni postume di zoologia Adriatica. Giovanni Cecchini, Venezia.

Rioja, E. - 1923. Estudio sistemático de las especies Ibéricas del suborden Sabelliformia. Trab. Mus. Nac. Cienc. Nat. Ser. Zool., 48: $1-144$.

Southern, R. - 1914. Clare Island Survey: Archiannelida and Polychaeta. Proc. Roy. Irish Acad., 31(47): 1-160.

Tovar-Hernández, M.A. - 2005. Species of Chone Krøyer, 1856 (Polychaeta: Sabellidae) from the Grand Caribbean Region. Zootaxa, 1070: 1-30.

Tovar-Hernández, M.A. - 2007. Revision of Chone Krøyer, 1856 (Polychaeta: Sabellidae) from North America and descriptions of four new species. J. Nat. Hist., 41: 511-566.

Tovar-Hernández, M.A. - 2008. Phylogeny of Chone Krøyer, 1856 (Polychaeta: Sabellidae) and related genera. J. Nat. Hist., 42(33-34): 2193-2226.

Tovar-Hernández, M.A. and P. Knight-Jones. - 2006. Species of Branchiomma (Polychaeta: Sabellidae) from the Caribbean Sea and Pacific coast of Panama. Zootaxa, 1189: 1-37.

Tovar-Hernández, M.A., M. Licciano and A. Giangrande. - 2007. Revision of Chone Krøyer, 1856 (Polychaeta: Sabellidae) from the Eastern Central Atlantic and Mediterranean Sea with descriptions of two new species. Sci. Mar., 71(2): 315-338.

Tovar-Hernández, M.A., N. Méndez and J. Salgado-Barragán. - 2009. Branchiomma bairdi: a Caribbean hermaphrodite fan worm in the south-eastern Gulf of California (Polychaeta: Sabellidae). Mar. Biod. Rec., 2: e43. doi: 10.1017/ S1755267209000463

Scient. ed.: D. Martin.

Received September 1, 2009. Accepted April 21, 2010.

Published online October 4, 2010. 